\title{
Update on the management of chronic obstructive pulmonary disease
}

\author{
Andrea K Maas ${ }^{1 *}$ and David M Mannino ${ }^{2}$
}

\author{
Addresses: ${ }^{1}$ Department of Pulmonary and Critical Care Medicine, University of South Carolina School of Medicine, Eight Medical Park, Suite 410, \\ Columbia, SC 29203, USA; ${ }^{2}$ Department of Preventive Medicine and Environmental Health, 121 Washington Ave, University of Kentucky Medical \\ Center, Lexington, KY 40536, USA \\ *Corresponding author: Andrea K Maas (andrea.maas@uscmed.sc.edu) \\ FI000 Medicine Reports 2010, 2:72 (doi:10.3410/M2-72)
}

The electronic version of this article is the complete one and can be found at: http://fl000.com/reports/medicine/content/2/72

\begin{abstract}
Chronic obstructive pulmonary disease is a highly prevalent, underdiagnosed, and undertreated chronic lung disease. Early and appropriate treatment may help modify the course of the disease with respect to exacerbation timing and frequency, quality of life, and mortality. Steady progress continues to be made in understanding the disease pathogenesis and treatment modalities, and there is some evidence that outcomes are improving.
\end{abstract}

\section{Introduction and context}

Chronic obstructive pulmonary disease (COPD) is a chronic progressive systemic inflammatory disease that is generally a response to noxious particles and gases (most often, tobacco smoke) in susceptible individuals, although second-hand smoke, aging, other pollutants, and HIV may also be associated with COPD. This disease is expected to be the third leading cause of mortality worldwide by 2020 [1]. It causes 2.7 million deaths worldwide per year $[2,3]$ and is associated with up to a twofold-higher risk of cardiovascular mortality [4-6]. Classically, COPD is a heterogeneous condition characterized by incompletely reversible airflow obstruction, including emphysema, chronic bronchitis, and bronchial hyperreactivity, often in combination. Phenotypes of COPD may be further classified on the basis of radiographic findings (i.e, the presence or absence of emphysema and/or bronchial wall thickening) or genetic polymorphisms. The main pathways studied in association with COPD development are the inflammatory, protease-antiprotease, and antioxidant pathways, but unfortunately many studies looking at genetic polymorphisms either have shown no association with COPD or had conflicting results, possibly related to the choice of study population $[7,8]$.
In 2001, the Global Initiative for Chronic Obstructive Lung Disease (GOLD) was formed to improve the investigation and management of this complex disease, and treatment strategies have been recommended on the basis of GOLD staging (Figure 1) [9]. Patients with respiratory symptoms but no airflow obstruction are also at increased risk for respiratory and cardiovascular morbidity and mortality [10]. Recent research has focused on identifying and modifying comorbidities associated with COPD and therapies to improve the significant individual and global morbidity and mortality associated with this disease.

Spirometry provides the single best method of diagnosing and staging COPD. The severity of COPD is staged according to the forced expiratory volume in 1 second $\left(\mathrm{FEV}_{1}\right)$, which is the most reproducible parameter of spirometric testing and the most significant predictor of prognosis in COPD $[11,12]$. In healthy individuals, $\mathrm{FEV}_{1}$ declines by $20-30 \mathrm{~mL}$ per year, but this decline is accelerated in patients with COPD [13]. Pharmacologic therapies for COPD have been assessed by measuring lung function decline, number and timing of exacerbations, and effect on mortality counterbalanced by the side effect profile. Exacerbation endpoints have been of particular 
Figure I. Chronic obstructive pulmonary disease (COPD) stages and treatment recommendations from the guidelines of the Global Initiative on Obstructive Lung Disease [9]

\begin{tabular}{|c|c|c|c|}
\hline \multicolumn{4}{|c|}{ COPD Stages } \\
\hline $1\left(\mathrm{FEV}_{1}>80 \%\right)^{*}$ & $2\left(\mathrm{FEV}_{1} 50-80 \%\right)$ & $3\left(\mathrm{FEV}_{1} 30-50 \%\right)$ & $4\left(\mathrm{FEV}_{1}<30 \%\right)$ \\
\hline $\begin{array}{l}\text { Risk factor } \\
\text { reduction } \\
\text { Influenza } \\
\text { vaccination } \\
\text { Symptomatic } \\
\text { treatment with } \\
\text { short acting agent }\end{array}$ & $\begin{array}{l}\text { Same as } 1 \\
\text { ADD regular } \\
\text { treatment with a } \\
\text { bronchodilator } \\
\text { ADD } \\
\text { rehabilitation }\end{array}$ & $\begin{array}{l}\text { Same as } 2 \\
\text { ADD inhaled } \\
\text { steroids if } \\
\text { repeated } \\
\text { exacerbations }\end{array}$ & $\begin{array}{l}\text { Same as } 3 \\
\text { ADD long term } \\
\text { oxygen if } \\
\text { hypoxemic } \\
\text { Consider surgical } \\
\text { interventions }\end{array}$ \\
\hline
\end{tabular}

${ }^{*}$ In all categories, $\mathrm{FEV}_{1} / \mathrm{FVC}$ is less than $70 \%$ of predicted following administration of an inhaled bronchodilator

FEV , forced expiratory volume in I second; FVC, forced vital capacity.

interest given that exacerbations have been associated with increased risk of myocardial infarction and stroke [14], decline in lung function [15], decline in quality of life, and an overall $14-18 \%$ 1-year mortality [16].

\section{Recent advances \\ Pharmacologic agents}

Long-acting antimuscarinic agents

Anticholinergic agents in COPD may be beneficial because of the increased vagal tone in the airways of patients with COPD [17]. Tiotropium is a once-daily, inhaled anticholinergic therapy that was recently examined in the 4-year UPLIFT (Understanding Potential Long-Term Impacts on Function with Tiotropium) trial [18]. In this study, patients were at least 40 years of age (mean age 64.5 ), $90 \%$ had GOLD stage 2 or 3 COPD, and more than $60 \%$ were already on long-acting betaagonists (LABAs) or inhaled corticosteroids (ICSs) (or both). Tiotropium was not shown to significantly reduce the rate of decline in $\mathrm{FEV}_{1}$ but was associated with improvements in quality of life, reduced time to first exacerbation (16.7 versus 12.5 months), delayed time to first hospitalization for an exacerbation, and a reduced mean number of exacerbations by $14 \%(P<0.001)$ during the 4-year period [18].

Long-acting bronchodilator and inhaled corticosteroids

The addition of a long-acting bronchodilator is recommended for patients with moderate $\left(\mathrm{FEV}_{1} /\right.$ forced vital capacity ratio of $<70 \%, \mathrm{FEV}_{1}$ of $<80 \%$ ) or worse COPD based on GOLD staging, and ICSs are recommended for patients with an $\mathrm{FEV}_{1}$ of less than $50 \%$ or with frequent exacerbations. Studies examining the effects of ICSs alone have not shown any effect on lung function decline over time and have had conflicting results in regard to exacerbation rate reduction [19-21].

Current LABA-ICS combinations are marketed under the trade names Advair (salmeterol/fluticasone propionate; GlaxoSmithKline, Uxbridge, Middlesex, UK) and Symbicort (formoterol/budesonide; AstraZeneca, London, UK). The TORCH (Towards a Revolution in COPD Health) trial examined the effects of salmeterol and fluticasone propionate on survival in COPD over the course of 3 years [10]. A non-statistically significant trend in improved survival was observed in patients receiving the LABA-ICS combination compared with placebo $(P=$ 0.052 ) or either of the individual components. The LABA-ICS combination group did have a reduced annual rate of exacerbations (1.13 to 0.85 ) and improved health status according to the St George's Respiratory Questionnaire [10]. A post hoc analysis found that treatment with salmeterol-fluticasone propionate reduced the rate of decline in $\mathrm{FEV}_{1}$ in patients with moderate to severe COPD - a finding that has not been demonstrated with other pharmacologic therapies [22].

\section{'Triple' combination therapy}

In one study, 660 patients with moderate, severe, or very severe COPD (mean $\mathrm{FEV}_{1} 1.1 \mathrm{~L}$ ) were randomly assigned to receive tiotropium plus placebo and tiotropium plus budesonide/formoterol over the course of 12 weeks. Patients on triple-combination therapy showed statistically significant improvement in their pre-dose and post-dose $\mathrm{FEV}_{1}$, capacity of daily living questionnaire, and COPD symptoms. Furthermore, the number of severe exacerbations was reduced by $62 \%$ (rate ratio 0.38, 95\% confidence interval [CI] 0.25-0.57, $P<0.001)$ [23].

In the OPTIMAL (Optimal Therapy of Chronic Obstructive Pulmonary Disease To Prevent Exacerbations and Improve Quality of Life) study looking at tiotropium in combination with salmeterol-fluticasone, lung function and quality of life were also shown to improve compared with tiotropium plus placebo or salmeterol alone over the course of 1 year. However, in this study, mortality and the proportion of patients who experienced an exacerbation did not differ between the groups, although the number of hospitalizations required because of an exacerbation was reduced in patients on tiotropium plus salmeterol-fluticasone (rate ratio 0.53, 95\% CI 0.33$0.86)[24]$. 


\section{Other pharmacologic treatments}

Other pharmacologic treatments for COPD have targeted the inflammatory process and cardiovascular comorbidity. Chronic low-dose macrolide therapy has been shown to reduce exacerbation frequency and shorten duration of exacerbations, although the antibacterial and antiinflammatory mechanisms remain unclear [25]. Roflumilast is an oral phosphodiesterase-4 inhibitor that showed improvements in lung function (39-mL increase in post-bronchodilator $\mathrm{FEV}_{1}$ compared with placebo, $P=0.001)$ and exacerbation frequency ( 0.86 versus 0.92 exacerbations/patient per year for roflumilast versus placebo) after 1 year of use in patients with severe COPD [26]. Roflumilast is currently under study in Europe, but the US Food and Drug Administration recently rejected the application for drug approval in the US because of concerns over possible adverse events such as the possibility that neuropsychiatric reactions would offset the 'modest' increase in lung function.

Mucolytics with anti-inflammatory and antioxidant activity such as carbocisteine have also been shown to reduce exacerbations in patients with moderate or worse COPD [27]. The 3-hydroxy 3-methylglutaryl coenzyme A reductase inhibitors (statins) may reduce the number of COPD exacerbations and mortality from COPD, presumably via anti-inflammatory mechanisms, although most previous studies do have inherent methodological limitations $[28,29]$. Likewise, treatment with beta-blockers may reduce the risk of exacerbations and improve survival in patients with COPD, possibly as a result of cardiopulmonary protective properties [30]. Exacerbation number and severity may also be reduced with treatment with non-typeable Haemophilus influenzae oral immunotherapeutic HI-164OV [31]. Vitamin D replacement is currently the subject of a placebo-controlled double-blinded randomized controlled trial [32].

\section{Side effects of treatment}

The use of ICSs causes some concern over the risk for osteoporosis and pneumonia. In the TORCH trial, osteoporosis was highly prevalent in patients with COPD (18\% of men and 30\% of women at baseline), but the use of ICSs had no significant effect on bone mineral density compared with placebo [33]. In contrast, a meta-analysis of 18 randomized controlled trials looking at the risk of pneumonia with long-term use (at least 24 weeks) of ICSs in COPD did find a significant increased risk of pneumonia (relative risk 1.60, 95\% CI 1.33-1.92, $P<0.001$ ) but without a significantly increased risk of pneumonia-related mortality or overall mortality [34]. Analysis of the TORCH study also found a greater risk of pneumonia in patients on ICSs alone or in combination compared with placebo ( 84 and 88 versus
52 per 1000 treatment-years, respectively) [35]. The definition of pneumonia (i.e., whether radiologic confirmation is required) may alter these findings. A metaanalysis looking at fatal and non-fatal cardiovascular events in patients treated with tiotropium found that tiotropium did not significantly increase the risk of adverse major cardiovascular events among patients with COPD [36].

\section{Other management modalities}

Because it ameliorates decline in lung function, smoking cessation remains the most important management issue in COPD patients who continue to smoke. Other considerations in the management of COPD include assessing the need for chronic oxygen therapy given that oxygen has been shown to improve mortality in patients with chronic respiratory failure [37]; referral for pulmonary rehabilitation, which improves quality of life [38] and exacerbation severity [39]; and the use of noninvasive ventilation, which improves quality of life with variable effects on survival $[40,41]$. Importantly, increased physical activity at home also translates into a substantially reduced risk of readmission due to a COPD exacerbation. Patients who walk at least 60 minutes a day had a statistically significant reduction in risk of hospital readmission by almost $50 \%$, and this association did not change when adjusted for COPD severity, nutritional status factors, or respiratory rehabilitation [42]. A recent study has suggested that abnormal coordination of swallowing may lead to prandial aspiration and trigger COPD exacerbations $[43,44]$.

Referrals for lung volume reduction surgery and lung transplant must also be considered for patients with COPD. Lung volume reduction surgery should be considered, especially for patients with both predominately upper-lobe emphysema and low-baseline exercise capacity, as this surgery offers a survival benefit, improved quality of life, and reduction in exacerbations. In contrast, patients with non-upper lobe emphysema and high-baseline exercise capacity are poor candidates and have a higher mortality than patients treated with medical therapy alone [45].

\section{Outcomes}

Recent data from the US suggest that COPD hospitalization rates are no longer increasing and that COPD mortality rates are starting to decrease $[46,47]$. These findings are encouraging and may be a result of improved diagnosis and better treatment.

\section{Implications for clinical practice}

COPD is now recognized as a systemic illness. Evidence supports the use of inhaled pharmacotherapy to improve 
lung function, quality of life, and exacerbation frequency and severity in patients with severe and very severe disease and in many patients with moderate disease. Until recently, only smoking cessation was found to reduce the decline in $\mathrm{FEV}_{1}$, but there are now some data that show that pharmacotherapy may also be effective [48]. Furthermore, early intervention may have effects that are more dramatic and decrease the time to first exacerbation [49]. Maintenance therapy for moderate to severe COPD with long-acting antimuscarinics and LABA-ICS combinations appears to provide benefits in health status, exacerbation rates, and probably mortality. We continue to recognize the important role that exacerbations play in the course of COPD, and therapy directed toward reducing exacerbation rate and severity will hopefully lead to further improvements in quality of life, lung function, and mortality.

\section{Abbreviations}

$\mathrm{CI}$, confidence interval; COPD, chronic obstructive pulmonary disease; $\mathrm{FEV}_{1}$, forced expiratory volume in 1 second; GOLD, Global Initiative for Chronic Obstructive Lung Disease; ICS, inhaled corticosteroid; LABA, long-acting beta-agonist; TORCH, Towards a Revolution in Chronic Obstructive Pulmonary Disease Health.

\section{Competing interests}

AKM declares that she has no competing interests. DMM has received research funding from GlaxoSmithKline (Uxbridge, Middlesex, UK), Pfizer (New York, NY, USA), Novartis (Basel, Switzerland), and AstraZeneca (London, UK) and has served as a consultant for GlaxoSmithKline, Pfizer, Novartis, Forest (New York, NY, USA), Boehringer Ingelheim (Ingelheim, Germany), and AstraZeneca.

\section{References}

I. Murray C], Lopez AD: Alternative projections of mortality and disability by cause 1990-2020: Global Burden of Disease Study. Lancet 1997, 349:1498-504.

2. Chapman KR, Mannino DM, Soriano JB, Vermeire PA, Buist AS, Thun MJ, Connell C, Jemal A, Lee TA, Miravitlles M, Aldington S, Beasley R: Epidemiology and costs of chronic obstructive pulmonary disease. Eur Respir J 2006, 27:188-207.

3. Mannino DM, Buist AS: Global burden of COPD: risk factors, prevalence, and future trends. Lancet 2007, 370:765-73.

4. Mannino DM, Doherty DE, Sonia Buist A: Global Initiative on Obstructive Lung Disease (GOLD) classification of lung disease and mortality: findings from the Atherosclerosis Risk in Communities (ARIC) study. Respir Med 2006, 100: I I5-22.

5. Curkendall SM, DeLuise C, Jones JK, Lanes S, Stang MR, Goehring E Jr, She D: Cardiovascular disease in patients with chronic obstructive pulmonary disease, Saskatchewan Canada cardiovascular disease in COPD patients. Ann Epidemiol 2006, 16:63-70.

6. Johnston AK, Mannino DM, Hagan GW, Davis KJ, Kiri VA: Relationship between lung function impairment and incidence or recurrence of cardiovascular events in a middle-aged cohort. Thorax 2008, 63:599-605.
7. Lomas DA, Silverman EK: The genetics of chronic obstructive pulmonary disease. Respir Res 200 I, 2:20-6

8. Smolonska J, Wijmenga C, Postma D, Boezen M: Meta-analyses on suspected chronic obstructive pulmonary disease genes: a summary of 20 years' research. Am J Respir Crit Care Med 2009, 180:6|8-3|.

9. Pauwels RA, Buist AS, Calverley PM, Jenkins CR, Hurd SS: Global strategy for the diagnosis, management, and prevention of chronic obstructive pulmonary disease. NHLBI/WHO Global Initiative for Chronic Obstructive Lung Disease (GOLD) Workshop summary. Am J Respir Crit Care Med 200I, 163:I256-76.

10. Calverley PM, Anderson JA, Celli B, Ferguson GT, Jenkins C, Jones PW, Yates JC, Vestbo J: Salmeterol and fluticasone propionate and survival in chronic obstructive pulmonary disease. N Engl J Med 2007, 356:775-89.

FI000 Factor 6.0 Must Read

Evaluated by Robert Keith 27 Apr 2007

II. Anthonisen NR, Wright EC: Bronchodilator response in chronic obstructive pulmonary disease. Am Rev Respir Dis I986, I33:8 |4-9.

12. Thomason MJ, Strachan DP: Which spirometric indices best predict subsequent death from chronic obstructive pulmonary disease? Thorax 2000, 55:785-8.

13. Celli BR, MacNee W: Standards for the diagnosis and treatment of patients with COPD: a summary of the ATS/ERS position paper. Eur Respir J 2004, 23:932-46.

14. Donaldson GC, Hurst JR, Smith CJ, Hubbard RB, Wedzicha JA: Increased risk of myocardial infarction and stroke following exacerbation of COPD. Chest 2010, 137:1091-7.

15. Donaldson GC, Wedzicha JA: COPD exacerbations .I: Epidemiology. Thorax 2006, 6I:164-8.

16. Johnston AK, Mannino DM: Epidemiology of COPD exacerbations. In Lung Biology in Health and Disease: Chronic Obstructive Pulmonary Disease Exacerbations. Volume 228. Edited by Wedzicha JA and Martinez FJ. New York: Informa Healthcare; 2008:15-26.

17. Gross NJ, Skorodin MS: Role of the parasympathetic system in airway obstruction due to emphysema. N Engl J Med 1984, 3II:42I-5.

18. Tashkin DP, Celli B, Senn S, Burkhart D, Kesten S, Menjoge S, Decramer M: A 4-year trial of tiotropium in chronic obstructive pulmonary disease. $N$ Engl J Med 2008, 359:1543-54.

19. Burge PS, Calverley PM, Jones PW, Spencer S, Anderson JA, Maslen TK: Randomised, double blind, placebo controlled study of fluticasone propionate in patients with moderate to severe chronic obstructive pulmonary disease: the ISOLDE trial. BMJ 2000, 320:1297-303.

20. Vestbo J, Sorensen T, Lange P, Brix A, Torre P, Viskum K: Longterm effect of inhaled budesonide in mild and moderate chronic obstructive pulmonary disease: a randomised controlled trial. Lancet 1999, 353:1819-23.

21. Pauwels RA, Lofdahl CG, Laitinen LA, Schouten JP, Postma DS, Pride NB, Ohlsson SV: Long-term treatment with inhaled budesonide in persons with mild chronic obstructive pulmonary disease who continue smoking. European Respiratory Society Study on Chronic Obstructive Pulmonary Disease. $N$ Engl J Med 1999, 340:1948-53.

22. Celli BR, Thomas NE, Anderson JA, Ferguson GT, Jenkins CR, Jones PW, Vestbo J, Knobil K, Yates JC, Calverley PM: Effect of pharmacotherapy on rate of decline of lung function in chronic obstructive pulmonary disease: results from the TORCH study. Am J Respir Crit Care Med 2008, 178:332-8.

23. Welte T, Miravitlles M, Hernandez P, Eriksson G, Peterson S, Polanowski T, Kessler R: Efficacy and tolerability of budesonide/ formoterol added to tiotropium in patients with chronic obstructive pulmonary disease. Am J Respir Crit Care Med 2009, 180:74I-50.

24. Aaron SD, Vandemheen KL, Fergusson D, Maltais F, Bourbeau J, Goldstein R, Balter M, O'Donnell D, Mclvor A, Sharma S, Bishop G, Anthony J, Cowie R, Field S, Hirsch A, Hernandez P, Rivington R, 
Road J, Hoffstein V, Hodder R, Marciniuk D, McCormack D, Fox G, Cox G, Prins HB, Ford G, Bleskie D, Doucette S, Mayers I, Chapman K, Zamel N, et al.; Canadian Thoracic Society/Canadian Respiratory Clinical Research Consortium: Tiotropium in combination with placebo, salmeterol, or fluticasone-salmeterol for treatment of chronic obstructive pulmonary disease: a randomized trial. Ann Intern Med 2007, 146:545-55.

\section{Changes Clinical Practice}

FI000 Factor 6.0 Must Read

Evaluated by Don Sin 25 Apr 2007

25. Seemungal T, Wilkinson T, Hurst J, Perera W, Sapsford R, Wedzicha J: Long-term erythromycin therapy is associated with decreased chronic obstructive pulmonary disease exacerbations. Am J Respir Crit Care Med 2008, I78: I 139-47.

FI000 Factor 4.8 Must Read

Evaluated by Robin D Taylor 16 Jan 2009, Guy Joos 10 Mar 2009

26. Calverley P, Sanchez-Toril F, Mclvor A, Teichmann P, Bredenbroeker D, Fabbri L: Effect of I-year treatment with roflumilast in severe chronic obstructive pulmonary disease. Am J Respir Crit Care Med 2007, I76:|54-6|.

27. Zheng J-P, Kang J, Huang S-G, Chen P, Yao W-Z, Yang L, Bai C-X, Wang C-Z, Wang C, Chen B-Y, Shi Y, Liu C-T, Chen P, Li Q, Wang Z-S, Huang Y-J, Luo Z-Y, Chen F-P, Yuan J-Z, Yuan B-T, Qian H-P, Zhi R-C, Zhong N-S: Effect of carbocisteine on acute exacerbations of chronic obstructive pulmonary disease (PEACE study): a randomized placebo-controlled study. Lancet 2008, 371:2013-8.

28. Blamoun A, Batty G, Debari V, Rashid A, Sheikh M, Khan M: Statins may reduce episodes of exacerbation and the requirement for intubation in patients with COPD: evidence from a retrospective cohort study. Int J Clin Pract 2008, 62: I373-8.

29. Frost, F, Petersen H, Tollestrup K, Skipper B: Influenza and COPD mortality protection as pleiotropic, dose-dependent effects of statins. Chest 2007, 13 1:1006-12.

30. Rutten F, Zuithoff N, Hak E, Grobbee D, Hoes A: Beta-blockers may reduce mortality and risk of exacerbations in patients with chronic obstructive pulmonary disease. Arch Intern Med 2010, 170:880-7.

FI000 Factor 3.0 Recommended

Evaluated by Phillip Lieberman 01 Jun 2010

31. Tandon MK, Phillips M, Waterer G, Dunkley M, Comans P, Clancy R: Oral immunotherapy with inactivated nontypeable Haemophilus influenzae reduces severity of acute exacerbations in severe COPD. Chest 2010, 137:805-II.

FI000 Factor 3.0 Recommended

Evaluated by Hajime Takizawa 15 Dec 2009

32. Janssens W, Lehouck A, Carremans C, Bouillon R, Mathieu C, Decramer M: Vitamin D beyond bones in chronic obstructive pulmonary disease: time to act. Am J Respir Crit Care Med 2009, 179:630-6.

33. Ferguson GT, Calverley PM, Anderson JA, Jenkins CR, Jones PW, Willits LR, Yates JC, Vestbo J, Celli B: Prevalence and progression of osteoporosis in patients with COPD: results from the TOwards a Revolution in COPD Health study. Chest 2009, 136: | 456-65.

34. Singh S, Amin AV, Loke $\mathrm{YK}$ : Long-term use of inhaled corticosteroids and the risk of pneumonia in chronic obstructive pulmonary disease: a meta-analysis. Arch Intern Med 2009, 169:219-29.

35. Crim C, Calverley PM, Anderson JA, Celli B, Ferguson GT, Jenkins C, Jones PW, Willits LR, Yates JC, Vestbo J: Pneumonia risk in COPD patients receiving inhaled corticosteroids alone or in combination: TORCH study results. Eur Respir J 2009, 34:64I-7.

FI000 Factor 3.2 Recommended

Evaluated by Klaus Dalhoff 15 Sep 2009, John Heffner 29 Sep 2009

36. Rodrigo GJ, Castro-Rodriguez JA, Nannini LJ, Plaza Moral V, Schiavi EA: Tiotropium and risk for fatal and nonfatal cardiovascular events in patients with chronic obstructive pulmonary disease: systematic review with meta-analysis. Respir Med 2009, 103:1421-9.

37. Continuous or nocturnal oxygen therapy in hypoxemic chronic obstructive lung disease: a clinical trial. Nocturnal Oxygen Therapy Trial Group. Ann Intern Med 1980, 93:391-8.

38. Lacasse $\mathrm{Y}$, Goldstein R, Lasserson TJ, Martin S: Pulmonary rehabilitation for chronic obstructive pulmonary disease. Cochrane Database Syst Rev 2006, 4:CD003793.

39. Griffiths TL, Burr ML, Campbell IA, Lewis-Jenkins V, Mullins J, Shiels K, Turner-Lawlor PJ, Payne N, Newcombe RG, lonescu AA, Thomas J, Tunbridge J: Results at I year of outpatient multidisciplinary pulmonary rehabilitation: a randomised controlled trial. Lancet 2000, 355:362-8.

40. Clini E, Sturani C, Rossi A, Viaggi S, Corrado A, Donner CF, Ambrosino $\mathrm{N}$ : The Italian multicentre study on noninvasive ventilation in chronic obstructive pulmonary disease patients. Eur Respir J 2002, 20:529-38.

41. Budweiser S, Hitzl AP, Jorres RA, Heinemann F, Arzt M, Schroll S, Pfeifer M: Impact of noninvasive home ventilation on longterm survival in chronic hypercapnic COPD: a prospective observational study. Int J Clin Pract 2007, 6I:1516-22.

42. Garcia-Aymerich J, Farrero E, Félez MA, Izquierdo J, Marrades RM, Antó JM; Estudi del Factors de Risc d'Agudització de la MPOC investigators: Risk factors of readmission to hospital for a COPD exacerbation: a prospective study. Thorax 2003, 58:100-5.

43. Gross RD, Atwood CW Jr, Ross SB, Olszewski JW, Eichhorn KA: The coordination of breathing and swallowing in chronic obstructive pulmonary disease. Am J Respir Crit Care Med 2009, 179:559-65.

44. Terada K, Muro S, Ohara T, Kudo M, Ogawa E, Hoshino Y, Hirai T, Niimi $A$, Chin $K$, Mishima M: Abnormal swallowing reflex and COPD exacerbations. Chest 2010, 137:326-32.

45. Fishman A, Martinez F, Naunheim K, Piantadosi S, Wise R, Ries A, Weinmann G, Wood DE; National Emphysema Treatment Trial Research Group: A randomized trial comparing lung-volumereduction surgery with medical therapy for severe emphysema. N Engl J Med 2003, 348:2059-73.

46. Brown DW, Croft JB, Greenlund KJ, Giles WH: Trends in hospitalization with chronic obstructive pulmonary diseaseUnited States, 1990-2005. COPD 2010, 7:59-62.

47. Polednak AP: Trends in mortality from COPD in selected U.S. states differing in tobacco control efforts. COPD 2010, 7:63-9.

48. Celli B, Decramer M, Kesten S, Liu D, Mehra S, Tashkin DP: Mortality in the 4-year trial of tiotropium (UPLIFT) in patients with chronic obstructive pulmonary disease. Am J Respir Crit Care Med 2009, 180:948-55.

49. Decramer M, Celli B, Kesten S, Lystig T, Mehra S, Tashkin DP: Effect of tiotropium on outcomes in patients with moderate chronic obstructive pulmonary disease (UPLIFT): a prespecified subgroup analysis of a randomised controlled trial. Lancet 2009, 374: $1171-8$.

FI000 Factor 3.0 Recommended Evaluated by Michael Morgan 20 Jan 2010 